\title{
Application of Tamarindus indica seed extract as bio-coagulant to removal suspended solids and colors
}

\author{
Agustin Dewi, Eri Iva Rustanti, Hermiyanti Pratiwi, Nerawati Diana A.T, Narwati \\ Department of Environmental Health, Poltekkes Kemenkes Surabaya, Indonesia
}

\begin{tabular}{l}
\hline \hline Article Info \\
\hline Article history: \\
Received Oct 7, 2020 \\
Revised Jan 22, 2021 \\
Accepted Mar 11, 2021 \\
\hline
\end{tabular}

\section{Keywords:}

Batik

Bio-coagulant

Tamarind seed extract

Wastewater

\begin{abstract}
The batik traditional industries in East Java, Indonesia generally not have a proper wastewater treatment plant yet, so liquid waste directly discharge into the river. Batik wastewater generally have a dark color, which derived from the coloring of naphthol with number of suspended solids greater than 100 $\mathrm{mg} / \mathrm{L}$ and color concentration more than 250 Pt.Co. Tamarind seed extract is known to contain natural polyelectrolytes active group, which had function as bio-coagulant. The research objective was to analyze the application of tamarind seed extract as bio-coagulant in wastewater treatment of the Batik traditional industries, by reducing suspended solids levels and color of wastewater. The research design used pretest and posttest control group design with variations of bio-coagulant doses of $10 \mathrm{ml} / \mathrm{L}, 30 \mathrm{ml} / \mathrm{L}$, and $50 \mathrm{ml} / \mathrm{L}$, and analyzed using the Two Way Anova Test. The results showed that the level of suspended solids in wastewater before treatment averaged $291 \mathrm{mg} / \mathrm{L}$, and the average color content was $593 \mathrm{Pt}-\mathrm{Co}$, so it did not meet the quality standards of the Governor of East Java No 72/2013. For the highest reduction in suspended solids levels at a dose of $10 \mathrm{ml} / \mathrm{L}$ reduced up to $95.1 \%$ and the highest decrease in color levels at a dose of $50 \mathrm{ml} / \mathrm{L}$, reduced up to $87.8 \%$. Traditional batik wastewater treatment, which used a coagulationflocculation process with bio-coagulant extract of tamarind seeds could reduce levels of suspended solids and colors, in order to meet the specified quality standards.
\end{abstract}

This is an open access article under the CC BY-SA license.

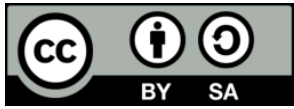

\section{Corresponding Author:}

Eri Iva Rustanti

Department of Environmetal Health

Poltekkes Kemenkes Surabaya

Pucang Jajar Tengah 56, Surabaya, Indonesia

Email: ivarust.eri@poltekkesdepkes-sby.ac.id

\section{INTRODUCTION}

Batik industry is one of the thousands of Indonesian cultures that have experienced a significant increase over time. In the process of batik production, they produce a large amount of liquid waste, as much as $80 \%$ of the total amount of water used in batik [1], [2]. The batik and textile industries produce wastewater from the coloring process, in addition to the high content of dyes; also contain ingredients that are synthetically difficult to be broken down.

Batik liquid waste produce dyes in the process of batik which is a big problem for the environment, because it can make the water conditions become turbid with the presence of dyes. Dyes contribute to organic content and wastewater toxicity. Batik liquid waste from the coloring process is dangerous for aquatic life in rivers and lakes, because it makes the waters become turbid, reduced light penetration and the presence of complex metal dyes that are poisonous to aquatic biota [3], [4]. 
Batik Jetis Sidoarjo is the home industry of batik crafts in Sidoarjo-East Java, Indonesia, which produce homemade batik [5]. The problems that occur in Kampung Batik Jetis Sidoarjo is the unavailable of the processing to wastewater before thrown into the river and the absence of a wastewater treatment plant from the production process before being discharged into the river. Waste directly discharged into the river contains high pollutants such as organic matter which can pollute the river [2], [5]. The characteristics of wastewater from the coloring process using naphthol dye obtained suspended solid (SS) levels of $675 \mathrm{mg} / \mathrm{L}$ with a $\mathrm{pH}$ of 4.3- 5.7, which exceeds the established quality standard [6].

In a study conducted by Nurroisah et al. [7], the processing of batik liquid waste with the characteristics of COD and suspended solids can be treated with aeration system tray and filtration methods that can reduce suspended solids by $87.31 \%$. The use of other methods carried out by [2], using several methods namely adsorption, coagulation and using anaerobic reactor baffle can reduce SS according to quality standards i.e. $1.0544 \mathrm{mg} / \mathrm{l}$ from $160 \mathrm{mg} / \mathrm{L}$. The aeration system waste treatment method of tray and filtration system is ineffective because it requires a rather long process, while the adsorption, coagulation, and anaerobic buffle reactor methods can reduce SS according to quality standards but require a fairly long processing process and require several materials for the liquid waste treatment process.

One method that can be used for liquid waste treatment in reducing organic material content is to use the coagulation and flocculation methods. Coagulation-flocculation is a physics-chemical method used in industrial wastewater treatment to remove colloidal particles, dissolved compounds and very fine suspended solids that exist in wastewater by destabilizing and floc formation [8]. Some researchers have shown that the use of natural coagulants that are environmentally friendly is a promising approach as an alternative in water and wastewater treatment, one of which is tamarind seeds (Tamarindus indica) [8].

Java tamarind seeds can be used as bio-coagulant in the coagulation process because they have protein content as much as $0.171-0.201 \mathrm{~g} / \mathrm{mL}$ [9], [10]. The protein contained in the Java Tamarind seeds is expected to play a role as a natural polyelectrolyte where the use is similar to synthetic coagulants. The efficiency of coagulation can be improved by extracting active components from Java tamarind seeds as natural coagulants by using saline solution. [11]. Tamarind seed coagulant extracted with water is only able to reduce turbidity $78 \%$ at a dose of $32 \mathrm{ml} / \mathrm{L}$, while the coagulant of seeds extracted with $1 \mathrm{M} \mathrm{NaCl}$ solution could reduce turbidity by $95 \%$ with a dose of $4 \mathrm{ml} / \mathrm{L} \mathrm{[12].} \mathrm{Extraction} \mathrm{using} \mathrm{NaCl}$ (salt) solution is a salting-in mechanism where ionic strength increases with addition and solubility of natural coagulants [11]. The purpose of this study is to analyze the ability of Java tamarind seed extract (Tamarindus indica) as a biocoagulant in reducing levels of suspended solid (SS) and color in liquid waste of batik home industry.

\section{RESEARCH METHOD}

\subsection{Types and design}

The research carried out was a pure experimental study (true experiment) with the design of a reexperiment research (pretest-posttest control group design). Subjects were randomly divided into treatment groups (X) and control groups that were not treated (-) [13], with a total sample of 24 samples. Variables in this research include bio-coagulant dose of java tamarind seed extract, stirring speed and stirring time. The effect of application of tamarind seed extract dose on the reduction of Fe content was analyzed using One Way Anova Test.

\subsection{Tools and materials}

The tools used in this study Jar Test equipment Model JT 203/6 with six 1L vats, suspended solid meter AMTAST TB200, pH (pH meter-PG1800 GEHAKA). A qualitative analysis to reveal the specific surface function groups on Tamarindus indica extract was performed by fourier transform infrared (FTIR) transmission spectra using $\mathrm{KBr}$ Technique. The analysis was carried out on MAGNA-IR 560, in the wave number of $400-4000 \mathrm{~cm}^{-1}$.

\subsection{Batik home industry wastewater}

The wastewater used as objects in this research came from the sump pit in the batik home industry, which was collected over five days. During the preservation process, wastewater was being stored at $4^{\circ} \mathrm{C}$.

\subsection{Java tamarind seed}

Java tamarind plant used in this research was obtained from local collectors in East Java, Indonesia. The seed were dried in the sun for approximately 12 hours [14]. The dried beans were mashed using a blender or pestle mortar until it became powder and sieved to a size of 80 mesh [15]. Powder that has been mashed then dissolved in n-hexane solution to remove fat content in a ratio of 1:5 (w/v), soaked for six hours, stirred using a magnetic stirrer with a rotation of $150 \mathrm{rpm}$ for 10 minutes, and leave it for 18 hours then 
strained and dried the powder at room temperature [14], [16]. The fat free Java tamarind powder (3 grams) then added with $100 \mathrm{ml}$ of $1.5 \mathrm{M} \mathrm{NaCl}$ solution to extract the protein on Java tamarind according to the procedure done by [17]-[22]. The resulting filtrate was used as bio-coagulant extract of Java tamarind seeds [22], [23].

\subsection{Coagulation-flocculation test}

Coagulation test-flocculation is done by the jar test method. Flash mixing was performed with a $\mathrm{G}$ factor $390 \mathrm{sec}^{-1}$ for 1 minute, followed by slow mixing for 15 minutes with $\mathrm{G}$ factor $50 \mathrm{sec}^{-1}$, and settling at room temperature for 30-60 minutes. Removal of suspended solids and color were selected as the dependent variable.

\section{RESULTS AND DISCUSSION}

In this section, it is explained the results of research and at the same time is given the comprehensive discussion. Results can be presented in figures, graphs, tables and others that make the reader understand easily [2], [5]. The discussion can be made in several sub-chapters.

\subsection{Wastewater of batik home industry}

In this research, the concentration of suspended solid (SS) of batik home industry wastewater was $1580 \mathrm{mg} / \mathrm{L}$, average initial $\mathrm{pH} 4-6$, settling time of sedimentation over 60 minutes, the color level was 610 Pt.Co.

\subsection{Characteristic of Java tamarind seed extract}

The identification of the coagulation functional groups was measured by the fourier transform infrared (FTIR) method. The FTIR method is used to obtain information on the presence of functional groups of molecules that have specific vibrational regions [11], so that quantitative/inorganic compounds can be identified quantitatively. Spectral cluster examination of the active Java tamarind seed extract is shown in Figure 1. FTIR test results in Figure 1 shows that specific peak absorption of tamarind seed powder extract occurs in the wavelength $3338.93 \mathrm{~cm}^{-1}, 2065.86 \mathrm{~cm}^{-1}$, and $1635.73 \mathrm{~cm}^{-1}$. The following is for the reading of FTIR test results of tamarind seed powder extract shows in Table 1.

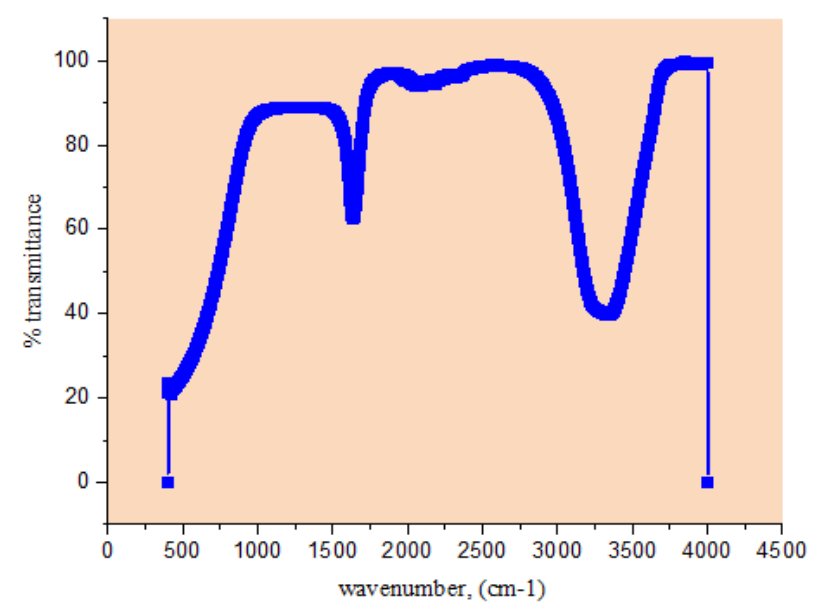

Figure 1. FTIR test result of Java tamarind seed powder extract

Table 1. FTIR Java tamarind seed extract

\begin{tabular}{cccc}
\hline Frequency area $\left(\mathrm{cm}^{-1}\right)$ & Functional groups & Peak absorprtion $\left(\mathrm{cm}^{-1}\right)$ & Transmitten \\
\hline $3330-3500$ & N-H (Amida)x & 3338.93 & 40 \\
$2000-3600$ & O-H (Alcohol, Phenol (H bond) & 2065.86 & 90 \\
$1610-1680$ & C=C (Alkena) & 1635.73 & 63 \\
\hline
\end{tabular}


Specific peak at around $3338.93 \mathrm{~cm}-1$ indicated the presence of $(\mathrm{N}-\mathrm{H})$ group, the peak at $1644 \mathrm{~cm}^{-1}$ indicated the presence of $\mathrm{C}=\mathrm{C}$ (alkene) group. The effect of bonding $\mathrm{O}-\mathrm{H}$ group was shown at the peak $2065.86 \mathrm{~cm}^{-1}$. These results confirmed the specific peak indicates that Java tamarind seed extract has aliphatic primary amides and primary, aliphatic alcohol function cluster. Amide cluster indicates the flocculant is positively charged, and hydroxyl cluster is charged negatively [9], [22], [24], [25]. SS levels after the addition of Java tamarind seed extract bio-coagulant. The results of SS levels after being treated with the addition of bio-coagulant extract of tamarind seeds with different dosage variations can be seen in Figure 2. The figure shows that SS levels in batik wastewater have decreased after the addition of biocoagulant extracts. The highest decrease occurred at a dose of $10 \mathrm{ml} / \mathrm{L}$, which is $76 \mathrm{mg} / \mathrm{L}$ or $95.1 \%$ removal FTIR Test Result of Java tamarind seed powder extract.

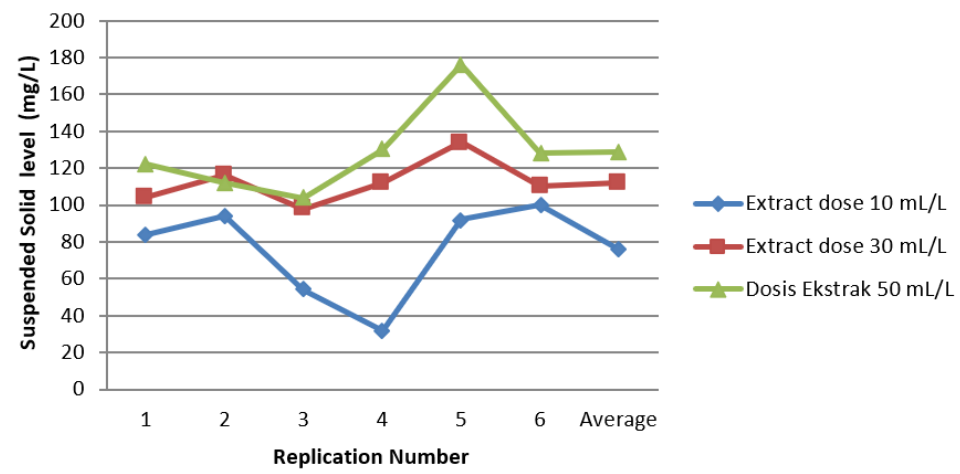

Figure 2. SS levels in batik wastewater

At a bio-coagulant dose of $30 \mathrm{ml} / \mathrm{L}$, the SS wastewater level becomes $112 \mathrm{mg} / \mathrm{L}$ or $92.9 \%$ removal. In affixing bio-coagulant extract by $50 \mathrm{ml} / \mathrm{L}$, the SS level in wastewater becomes $129 \mathrm{mg} / \mathrm{L}$ or with $91.8 \%$ removal. The results of statistical analysis with Two Way Anova Test on treatment data obtained Sig. $(\rho)$ 0.001. It means that the use of tamarind seed extract as bio-coagulant can significantly reduce SS levels. Color levels after the addition of bio-coagulant Java tamarind seed extract. The results of the examination of the color levels after being treated with the addition of bio-coagulant extract of Java tamarind seeds with different dosage variations it can be seen in Figure 3.

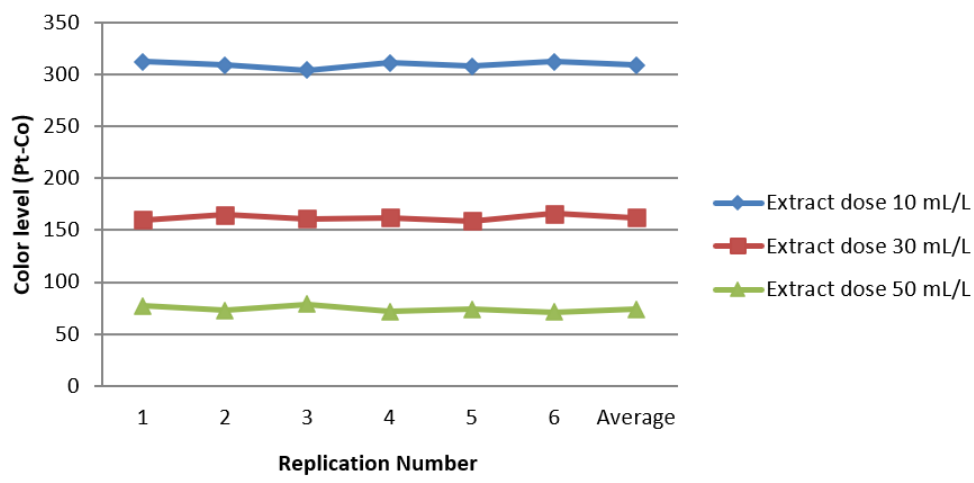

Figure 3. Color levels after the addition of bio-coagulant Java tamarind seed extract

Figure 3 shows that bio-coagulant extract at a dose of $10 \mathrm{ml} / \mathrm{L}$ can reduce the color concentration of waste by $49.3 \%$ or $309 \mathrm{Pt}-\mathrm{Co}$. Bio-coagulant at a dose of $30 \mathrm{ml} / \mathrm{L}$, decreases by $73.4 \%$ or $162 \mathrm{Pt}-\mathrm{Co}$, while at a dose of $50 \mathrm{ml} / \mathrm{L}$ can reduce color levels up to $74 \mathrm{Pt}-\mathrm{Co}$, or $87.8 \%$ removal and has fulfilled the Governor of Java East-Indonesia regulation, maximum of $200 \mathrm{Pt}-\mathrm{Co}$ [26]. Based on the results of Two Way Anova Test analysis, it shows the value of Sig. $(\rho)$ treatment of 0.0001 . It means that the use of tamarind seed extract as bio-coagulant can significantly reduce the color concentration of wastewater. 
Mechanism of coagulation-flocculation with Java tamarind seed extract. Wastewater of batik home industry is acid colloid ( $\mathrm{pH}<7)$ and stable. In acidic conditions, alum does not function optimally, because no charge of neutralization in the suspension occurs. Extract bio-coagulant of tamarind seed can function as a flocculant because it contains water-soluble protein with low molecules [15], [27]. Bio-coagulant extract from the seeds of tamarind has active groups of polyelectrolytes that are positively and negatively charged, namely the amide and hydroxyl groups. The most likely mechanism that occurs in the tamarind flocculation process is the adsorption and the neutralization of stress or adsorption and unstable particle bonds. It is very difficult to determine which mechanism happened first, because it happened simultaneously [26]. Active groups with negative charges released into the solution will react with positive ions or positive metal ions in colloids and form heavier flocks. On the other hand, the positive charge will react with hydroxyl ions in suspension, to neutralize the $\mathrm{pH}$ [22], [28], [29]. The coagulation-flocculation process is also influenced by the $\mathrm{G}$ factor (gradient of stirring speed), both fast and slow stirring. In the research the $\mathrm{G}$ value of the factor has been controlled to produce optimal SS and color removal. Research conducted by [30], [31] states that the optimum $\mathrm{G}$ of fast and slow stirring for the flocculation coagulation process is 390 seconds- 1 and 50 seconds-1. Determination of the value of the $\mathrm{G}$ factor is an important factor, because a $\mathrm{G}$ that is too large will inhibit the formation of flocks or flocks will break again [32].

\section{CONCLUSION}

The results of bio-coagulant examination from the extract of tamarind seeds showed that the protein content had a functional group of $\mathrm{N}-\mathrm{H}$ (Amide), $\mathrm{O}-\mathrm{H}$ (Alcohol), and $\mathrm{C}=\mathrm{C}$ (Alkene) polyelectrolytes. The largest active group of polyelectrolytes in bio-coagulants is the hydroxyl group. The presence of amides and hydroxyl will disrupt the colloidal stability of batik waste water, and form a large floc so that it can be sedimented. The highest reduction in SS occurred at a dose $10 \mathrm{ml} / \mathrm{L}$, which was $95.1 \%$ removal, while for the highest removal in color occurred at a dose of $50 \mathrm{ml} / \mathrm{L}$, which was $87.8 \%$. Traditional batik wastewater treatment, which used a coagulation-flocculation process with bio-coagulant extract of tamarind seeds could reduce levels of suspended solids and colors, in order to meet the specified quality standards. Tamarind seeds extract can be used in large scale batik crafts industries.

\section{REFERENCES}

[1] Apriyani, Nani, "Batik Industry: Liquid Waste Content and Its Processing Methods," Media Ilmiah Teknik Lingkungan, vol. 3, no. 1, pp. 21-29, 2018.

[2] Suprihatin, Hani, "Organic content of Jetis Sidoarjo Batik Liquid Industry and its Alternative Processing," Pusat Penelitian Lingkungan Hidup Universitas Riau., pp. 130-138, 2014.

[3] Mishra, Anuradha, Bajpai, and Malvika, "Flocculation behaviour of model textile wastewater treated with a food grade polysaccharide," Journal of Hazardous Materials, vol. 118, pp. 213-217, 2005. doi: 10.1016/j.jhazmat.2004.11.003.

[4] Fidiastuti, H.Rachman, Lathifah, and A. Samrotul, "Test on Characteristics of Tulungagung Batik Wastewater Industry: Preliminary Research,” Seminar Nasional Pendidikan Biologi dan Saintek III, pp. 296-300, 2018.

[5] Rochma, Nikmatul, Titah, and H. Sulistyaning, "Reducing BOD and COD of Batik Industry Liquid Waste Using Activated Carbon Through a Batch Adsorption Process," Jurnal Teknik ITS., vol. 6, no. 2, pp. 324-329, 2017.

[6] East Java Governor Regulation Number 72 of 2013 concerning Wastewater Quality Standards for Industry and / or Other Business Activities in East Java.

[7] Nurroisah, E., Indarjo, Sofwan, Wahyuningsih, and A. Setyo, "The Effectiveness of Tray and Filtration System Aeration as Reducing Chemical Oxygen Demand and Suspended Solids in Batik Liquid Waste," Unnes Journal of Public Health, vol. 3, no. 4, pp. 56-64, 2014.

[8] Ayangunna, R. Ruth, Giwa, Saidat O., Giwa, and Abdulwahab, “Coagulation- Flocculation Treatment of Industrial Wastewater Using Tamarind Seed Powder," International Journal of ChemTech Research., vol. 9, no. 05, pp. 771780, 2016.

[9] Hendrawati, Syamsumarsih, Delsy and Nurhasni, "Use of Java Tamarind Seeds (Tamarindus indica L.) and Winged Beans (Psophocarpus tetragonolobus L.) As Natural Coagulants in Improving Groundwater Quality," Valensi, vol. 3, no. 1, pp. 23-34, 2013.

[10] Puspasari and Fitri, "Utilization of Tamarind Seed (Tamarindus indica) As Alternative Coagulant in Tofu Industry Liquid Waste Management," Electronic Thesis, Politeknik Negeri Sriwijawa Palembang, 2014.

[11] Sya'banah and Nishfu, "Effectiveness of Moringa Oleifera Seed Extract as Coagulant for Phosphate Samples," Electronic Thesis, Univ. Islam Negeri Maulana Malik Ibrahim Malang, 2016.

[12] Y. P. Prihatini, "Effectiveness of Moringa Oleifera L. Moringa Seed Extract NaCl Extract Fat Free as Coagulant of Begawan River Solo Water,” Electronic Thesis, Univ. Islam Negeri Maulana Malik Ibrahim Malang, 2014.

[13] Eri, R. Iva, Hadi, Wahyono, Slamet, and Agus, "The Ability of a Natural Flocculant "Moringa Oleifera" In Reducing the Amount of Seawater Reverse Osmosis Reject Water's Dissolved Solids," APRN Journal of Engineering and Applied Sciences, vol. 13, no. 7, pp. 2443-2452, 2018. 
[14] Purnamasari, R. Devi, Iryani, Ani, Aminingsih, and Tri, "Utilization of Pigs (Vicia faba) and Tamarind Seeds (Tamarindus indica L) as natural coagulants in the process of improving water quality," Electronic Thesis, Univ. Pakuan, 2017.

[15] Enrico and Bernard, "Utilization of Tamarind Seed (Tamarindus indica) As Alternative Coagulant in the Process of Purifying Tofu Liquid Waste," Electronic Thesis, Univ. Sumatera Utara, 2018.

[16] Istiqomah, "Comparison of Maceration and Socletation Extraction Methods on the Levels of Piperin Java Chili (Piperis retrofracti fructus)," Universitas Islam Negeri Syarif Hidayatullah, 2013.

[17] Okuda, T., Baes, A.U., Nishijima, W., and Okada, M., "Coagulation Mechanism of Salt Solution-Extracted Active Component in Moringa oleifera Seeds," Water Research, vol. 35, no. 3, pp. 830-834, 2001.

[18] Sánchez-Martín, J., Beltrán-Heredia, J., and Peres, J. A., "Improvement of the flocculation process in water treatment by using Moringa oleifera seeds extract," Brazilian Journal of Chemical Engineering, vol. 29, no. 3, pp. 495-501, 2012.

[19] Fatehah, M.O., Hossain, S., and Teng, T.T., "Semiconductor Wastewater Treatment Using Tapioca Starch as a Natural Coagulant," Journal of Water Resource and Protection, vol. 5, no. 11, pp. 1018-1026, 2013.

[20] Aslamiah, S.S., Yulianti, E., and Jannah, A., "Coagulation Activity of Kelor Seed Extract (Moringa oleifera L.) in $\mathrm{NaCl}$ Solution to Liquid Waste PT. SIER PIER Pasuruan,” Alchemy, vol. 2, no. 3, pp. 178-183, 2013.

[21] Prihatinningtyas, "Natural Coagulant Application from Corn Flour in Clean Water Treatment," Jurnal Teknosains, vol. 2, no. 2, pp. 1-26, 2013.

[22] Eri, R. Iva, Hadi, Wahyono Slamet, and Agus, "Clarification of Pharmaceutical Wastewater with Moringa oleifera: Optimization Through Response Surface Methodology," Journal of Ecological Engineering (JEE), vol. 19, no. 3, pp. 126-134, 2018.

[23] Riantini and Farahiyah Eki, "Characterization of Bioactive Components and Activity Test of Java Tamarind (Tamarindus indica L.) NaCl Extract Against Nitrate (NO3-)," Electronic Thesis, Univ. Islam Negeri Maulana Malik Ibrahim Malang, 2014.

[24] Syauqi, A., Septiana, H. and Laili, S., "Carbocationation interpretation in suspension of tamarind seed (tamarindus indica) with $\mathrm{pH}$ and conductivity effects," e-Journal Ilmiah Biosaitropis, vol. 1, no. 1, no. 1-8, 2015.

[25] Hardi, Fulan Oktaviana, W., S. B. Eko, Hermiyanti, and Pratiwi, "Tamarind Seed Extract (Tamarindus indica) As A Coagulant of Tempe Industrial Liquid Waste,” Gema Kesehatan Lingkungan, vol. 15, no. 3, pp. 63-68, 2017.

[26] De Paula, H.M., De Oliveira Ilha, M.S., and Andrade, "Concrete plant wastewater treatment process by coagulation combining aluminum sulphate and Moringa oleifera powder," Journal of Cleaner Production, vol. 76, 2014.

[27] Kartika, Dita, Nurjazuli and Budiyono, "The ability of java tamarind seed powder in reducing ss, turbidity, and ammonia liquid waste treatment of PT. Utama Multiniaga Indonesia," Jurnal Kesehatan Masyarakat (e-Journal), vol. 4, no. 4, pp. 917-924, 2016.

[28] Harfouchi, H, Hank, D, and Hellal, A, "Response surface methodology for the elimination of humic substances from water by coagulation using powdered Saddled sea bream scale as coagulant aid," Process Safety and Environmental Protection, vol. 99, pp. 216-226, 2016.

[29] Ramadhani, G. Intan, Moesriati, and Atiek,"Utilization of tamarind seed (tamarindus indica) as alternative coagulant in the process of reducing COD and BOD levels with case study on tempe industry liquid waste," Jurnal Teknik Pomits, vol. 2, no. 1, pp. 22-26, 2013.

[30] Fitriani and A. Elok, "Reduction of methyl orange concentration by variation of coagulant doses of $\mathrm{NaCl}$ extract of Java Acid and the pH of solution and concentration of methyl orange," Electronic Thesis, Univ. Islam Negeri Maulana Malik Ibrahim Malang, 2016.

[31] Martina, Angela, Effendy, D. Santoso, Soetedjo, and Jenny N. M, "Application of Java acid coagulant seeds in decreasing concentration of drimaren red dyes in synthetic textile waste in various operations," Jurnal Rekayasa Proses, vol. 12, no. 2, pp. 40-45, 2018. doi: 10.22146/jrekpros.38948.

[32] Anggarani, B. O., Karnaningroem, N. and Moesriati, A, "Increasing the effectiveness of the coagulationflocculation process using aluminium sulphate and super floc," Undergraduate Research Report, Repository Institut teknologi Sepuluh Nopember Surabaya, pp. 1-9, 2015. 